\title{
Going "Rogue": National Parks, Discourses of American Identity and Resistance on Twitter
}

\author{
Joanne Marras Tate, Vincent Russell, Rachel Larsen, \\ and Ellie Busch
}

\section{INTRODUCTION}

Shortly after the inauguration of President Donald Trump, his administration directed several federal agencies, including the Environmental Protection Agency, the Department of Agriculture, the Department of Health and Human Services, and the Department of the Interior, which oversees the National Park Service (NPS), to limit contact with the public (Davis, 2017; Perez, 2017). In defiance, the Badlands National Park official Twitter account issued a series of tweets on January 24, 2017 about climate change that quickly went viral. The tweets were later deleted, and the public acknowledged this action as censorship of discussions about

\footnotetext{
J. Marras Tate $(\bowtie) \bullet$ V. Russell $\bullet$ R. Larsen $\bullet$ E. Busch

Department of Communication, University of Colorado Boulder, Boulder, CO, USA

e-mail: Joanne.MarrasTate@colorado.edu; Vincent.Russell@colorado.edu;

Rachel.Larsen@colorado.edu; Ellie.Busch@colorado.edu

(C) The Author(s) 2020

G. Bouvier, J. E. Rosenbaum (eds.), Twitter, the Public Sphere, and

the Chaos of Online Deliberation,

https://doi.org/10.1007/978-3-030-41421-4_2
} 
climate change by the new administration (Diaz, 2017). By January 26, 2017 , less than a week after the inauguration, more than ten "rogue" national park Twitter accounts (including @AltUSNatParkService, @ BadHombreNPS, and @AltYellowStone) sprung up in response to this censorship (Noe, 2017). In this paper, we argue that these alternative or rogue national park Twitter accounts functioned as a digital site of discursive resistance to the Trump administration's communication agenda. We discuss how three accounts that were covertly created and managed by National Park government employees drew on discourses of US national identity to construct identities of resistance, while situating themselves within larger historical discourses of national parks and American symbolism.

National parks are an important signifier of national identity (Burns, 2009; Runte, 2010; Tyrrell, 2012) and as such constitute a significant component of the nationalistic rhetoric associated with place-myths (Rennie, 2006; Runte, 2010). Hence, we begin this chapter with a historical overview of the NPS, wherein we discuss how parks have embodied democratic ideals (Frome, 2015; Ross-Bryant, 2005; Runte, 2010). Next, we present the findings from our Critical Discourse Analysis into what has, in some places, become a part of the everydayness of talk (Tracy \& Robles, 2013): the practice of tweeting. We identify how rogue National Park Twitter accounts evoked nationalism, resisted government, and strove to uphold democratic values.

Our research centers on the rogue national park Twitter accounts, as they became an exemplar of how tweets have become part of the process through which social values are constructed. Moreover, these accounts serve as a case study for examining civic participation on Twitter, allowing us to investigate how Twitter works as a public communicative space that encourages public engagement through a networked public sphere (Ausserhofer \& Maireder, 2013; Chen, Tu, \& Zheng, 2017). Conducting an analysis of discourses created by these rogue accounts is a way to further understand how this networked public sphere helps shape the meanings associated with the US national parks, providing an in-depth understanding of the nature of the US national identity constructed on Twitter. This investigation provides insight into how these constructs circulate and evolve on Twitter, allowing for the examination of Twitter's potential as a public sphere. 


\section{Foucault and Identity Construction}

This chapter, with its focus on the ways in which rogue accounts construct American identity through the use of historical symbols, relies on Foucault's The Archaeology of Knowledge (1972). Foucault provides a framework that allows us to understand how the selected rogue Twitter accounts socially construct the national parks' symbolic identity within significant historical contexts, with the idea of the "document" (p. 6) used here to describe history construction in the form of tweeting as a historical discourse. Because Foucault emphasizes examining nondominant discourses as a way to bring them to the forefront, we use Critical Discourse Analysis (CDA) to investigate discourses happening on a platform that, although public, does not always align with mainstream societal discourse. CDA enables us to highlight societal struggles and gaps in values by assessing "what exists, what might exist and what should exist" (Fairclough, 2013 , p. 7). CDA connects to the idea of archaeology as well by serving as a means to investigate the general histories present in the discourses created to represent the national parks, which are embedded within its constructed nationalistic history. Foucault (1972) points out that:

\footnotetext{
"[This] history in its traditional form, undertook to 'memorize' the monuments of the past, transform them into documents, and lend speech to those traces which, in themselves, are often not verbal, or which say in silence something other than what they actually say; in our time, history is that which transforms documents into monuments." (p. 7, emphasis added)
}

In a similar manner, the digital platform of Twitter works to bring historical significance to the US NPS by allowing for the creation of these rogue Twitter accounts and hosting the subsequent discourse constructed on Twitter. The Twitter platform is a unique, dynamic document that works to change and uphold the historical stories of the NPS.

In examining nondominant discourses, Foucault (1972) argues that a discursively oriented methodology "makes it possible to rethink the dispersion of history in the form of the same" (p. 21) and "to master time through a perpetually reversible relation between an origin and a term that are never given, but are always at work" (p. 22). Discursive practices showcased as alternative enact, through language, the various power struggles at play. The sociopolitical context of the tweets makes these struggles 
visible, while still holding on to notions of US national identity and their social construction.

Through the identity-work employed by the rogue accounts, we emphasize that "talk does identity-work [and] identities shape talk" (Tracy \& Robles, 2013, p. 7), and show that the Twitter accounts under analysis use their association with the national parks to construct American national identity, while simultaneously using the symbol of the national parks to construct a discourse of resistance. We emphasize that identity constructed through symbols is imbued with expected ways of being, which work in a dissenting and assenting way toward the construction of national identity. In other words, the use of national symbols, like those associated with the NPS, have the ability to uphold existing identities, enforcing an existing and familiar identity, while also having the ability to use those symbols as a strategy to enact resistance. Resistance, then, works as an identity-builder of the NPS, being discursively engaged in order to maintain historical notions and collective identities (Milan, 2015).

In the remainder of this chapter, we review literature on digital activism and provide a CDA of tweets by three "alternative" or rogue national park Twitter accounts in the weeks following their creation. We conclude that the rogue NPS Twitter accounts represent an emergent discursive rupture about governmental censorship on online platforms functioning as networked public spheres. The accounts sought to reclaim the historical mission of the parks as advocates for democratic values of public access, transparency, and justice-all while constructing US national identity through concepts of wilderness.

\section{The National Park Imaginary and US Identity}

To situate the history(ies) of US national parks, we point to Foucault's (1972) framework of history as a "discontinuity" that "enables the historian to individualize different domains but can be established only by comparing those domains" (p. 9). This brief history of the national parks strives to problematize patriotic assumptions about the parks' founding and use. The concept of discontinuity informs this project's deconstruction of history by emphasizing the relationship between power and history and attempting to disrupt existing power relations by acknowledging multiple histories. Historical discontinuity provides a means to understand how national parks serve an important function in the US imaginary (Howkins, Orsi, \& Fiege, 2016), for national identity continues 
inexorably to be tied to landscapes and romantic narratives (DeLuca \& Demo, 2000; Frome, 2015). We will thus compare various historical domains to discontinue ongoing discourses about the importance of public lands for US national identity.

In the United States, public lands have always been closely tied to modern notions of American national identity. Modern American civilization, according to Nash (2014), was based on ideals of wilderness, in which "vast, largely unmodified regions would be very close to absolute wilderness" (p. 7), with national parks functioning as a symbol for national identification, institutionalized through the history of public lands and later through the creation of the NPS (Nash, 2014). The US idea of public lands was shaped by several events before it was concretized into the creation of the NPS.

Thomas Jefferson's writings from the late 1700s were key in the process of creating the national parks. He described the land as unique to the United States (Runte, 2010; Tyrrell, 2012), while in the middle of the eighteenth century Henry David Thoreau (1990) inspired ideals of life and spiritual meaning to living with nature, further consolidating ideals of wilderness with the American landscape and the identity bound to it. Despite the inclusive rhetoric of these early national park advocates, the imaginary of the US wilderness was directed primarily to upper-class white people (DeLuca, 2010), who determined and constructed ideals of who could have access and the ways in which natural spaces should be enjoyed (Finney, 2014). Later events that shaped American wilderness imagery included the critique of the commercialization and distribution of property ownership at Niagara Falls, an event that contradicted the dominant American values of landscape democracy and equal access, and showed how most people valued the enjoyment of a pristine location over its capital exploitation (Runte, 2010). These developments revealed how the construction of a national symbol such as the wilderness spaces that later became the NPS was paramount for the United States in a moment when separating identities from Europe was perceived as an essential step toward the development of distinctions between people, architecture, and landscapes (Runte, 2010; Tyrrell, 2012).

The US national imaginary has always relied on images and discourses that maintained the idea of public lands. This included paintings such as Albert Bierstadt's 1863, The Rocky Mountain, Lander's Peak, which demonstrates the process by which popular media of the time were able to broadcast the grandeur of the West, thereby supporting the reputation of 
a stunning American scenery (Runte, 2010). These discourses culminated in 1864 when Abraham Lincoln established Yosemite Park, and later in 1906 with Theodore Roosevelt's establishment of Yellowstone National Park and the establishment of the NPS in 1916 (Brinkley, 2009). Most recently, the use of imagery to define and maintain US identity is seen in National Parks: America's Best Idea (Dir. Ken Burns, 2009). This is a documentary series that leads the viewer on a journey into the world of National Parks and their historical roots. This documentary series showcases selective narratives, where wilderness is reduced but survives within the ideals upheld by upper-class white people about what National Parks are (DeLuca, 2010) — and with it — their ideals of US identity (Nash, 2014).

National parks are thus seen as a legacy to US heritage and customs, where the romanticized narratives of the Wild West, the conquering of Native Americans, as well as the figure of the pioneer and the idea of a pristine wilderness, continue to exist (DeLuca \& Demo, 2000). These narratives were present almost immediately upon the creation of the NPS: DeLuca's and Demo's (2000) analysis of Carleton Watkins' early photographs of Yosemite demonstrates how these images constructed the national myth of pristine nature. This was a myth made material in the "pristine paradise," while at the same time it marginalized other cultures' visions of nature and human-nature relations, particularly that of Native Americans. According to DeLuca and Demo (2000), the construction of pristine wilderness as a production was evident and aided the "socially constructed ideas in the United States" such as preservation of the "wild" and conservation as a product of American experiences (Tyrrell, 2012, p. 1).

\section{Twitter Activism and the National Park Service}

The rogue national park Twitter accounts created after the 2017 determination for limiting of communication by government agencies and departments serve as a reminder of the potential of social media as a form of resistance. Using social media to resist the government is nothing new: Twitter has been used for active resistance in many other cases. In 2011, the Occupy Wall Street movement and the Arab Spring, in many senses, showcased how social media can be a tool for aggregating resistance, and how new technologies were said to have "a key role in the organization and diffusion of protest" (Tudoroiu, 2014, p. 346). As Tindall and Robinson (2017) explain, even though social networks have been 
statistical predictors of public participation, they do not operate in isolation. Essentially, social networks are facilitators of social processes. Social media and new technologies, therefore, are less about creating new forms of advocacy and activism and instead facilitate already "established modes of collective action” (Stoddart \& Macdonald, 2011, p. 329).

Literature points to the specific contributions of social media as a space for political advocacy, activism, and other forms of resistance. Obar (2014) notes how social media technology offers ways of communicating that are different from offline modes and traditional forms of computer-mediated communication (p. 212), exemplified by the rogue NPS accounts' resistance and advocacy.

Social media, like Twitter, continue to serve as platforms for activism and discursive resistance in order to uphold "democratic agency beyond traditional means of civic participation” (Milan, 2017, p. 2). Milan (2016) notes that such platforms are a means to expose contradictions encountered within the system, as they encourage public participation as well as engagement in critical thinking. As Shirky (2008) indicates, the advent of new technology has provided people with an increased ability to collaborate and engage in collective action, outside of established institutions and frameworks. Indeed, social media activism provides unique affordances and offers the potential to reach wider audiences and engage in activism from remote locations. Twitter use by different members of the public sphere has made it a platform that is part of a networked sphere, where issues of political stance are openly negotiated (Ausserhofer \& Maireder, 2013).

In addition, research suggests that there is a positive association between "being exposed to online information and political participation" (Scherman, Arriagada, \& Valenzuela, 2015, p. 153). Thus, social media opens up a space for the potential increase of political engagement by individuals. In the case of the rogue accounts, it opened up a space for engagement with public opinion, open critique of government officials and institutions, as well as the ability to share governmental information about the national parks, which also relied on notions of collective US national identity.

Notions of collective identity are often understood as either a "necessary condition for mobilization to occur" or as "an important outcome of social movement processes" (p. 11). Tindall and Robinson (2017) showed how these notions have an important relationship to one's participation in ongoing activism as well as with one's social media network 
embeddedness. Social media platforms, by providing a space for engaged participation on social issues, whether motivated by advocacy groups or more general social movements, allow for the mobilization of collective identity through their network capabilities. The rogue accounts allowed for this kind of mobilization by opening up a space for different American identities to unify under one denominator: national parks (Spillman, 2017; Wes, 2017).

\section{National Identity in Connection to Land on Twitter}

Tracy and Robles's Everyday Talk (2013) delves into how people infer different meanings about particular discourses and utterances in order to make sense of a conversation, and of themselves. The ordinary moments of daily conversation reflect, sustain, build, and challenge people's identities. According to Tracy and Robles (2013), identity encompasses the most personal aspects, personalities, and attitudes. A national identity tends to be identified by the "ways in which the citizens of a country talk about what defines them as a country" (Hahn, Judd, \& Park, 2010, p. 124).

Geographic constraints and proximity can contribute to the development of group identity, especially when deemed essential to the group's security and vitality (Herb \& Kaplan, 1999). The actual space, particular terrain, location, historic legacy, as well as unique natural features help establish such identification (Herb \& Kaplan, 1999). National parks are an example of how such associations of land and wilderness formed a foundation for the United States as a country, with wilderness discourses serving nationalistic exigencies (DeLuca \& Demo, 2001). In addition to shared histories and beliefs of freedom, people connect with the land through the social constructions established by the nation-state, including the ideal of American land embodying the American nation (Burns, 2009). This ideal can be observed in the citizenship rights established in the US Constitution: anyone born on American soil is guaranteed citizenship (Hahn et al., 2010). National parks functioned as a culturally significant foundation that were - and are-disseminated through media productions and everyday talk. Herb and Kaplan (1999) state that foundations may solidify identities because “only territory provides tangible evidence of the nation's existence and its historical roots" (p. 10). The national parks enhanced the 'wilderness' narratives and discourse, with, for example, Yosemite's valley 
offering cultural legitimacy to a nation seeking heritage (DeLuca \& Demo, 2001).

Social media today is one of the ways in which citizens can engage in political communication in the public sphere (Ausserhofer \& Maireder, 2013). According to Milan (2015), social media has a role in activists' meaning construction processes and in the "circulation of meaning" (Milan, 2015, p. 890), by significantly contributing to "structure modes of interactions and relationships" where a collective identity allows users to recognize themselves in a collective "we" (Milan, 2015, p. 891).

National parks, as land and therefore a concrete object, are reflected on Twitter through the use of images and discourse practices that digitally mediate American identity as a collective within the platform (Milan, 2015). In particular, collective identity through the processes of interaction and sharing is amplified by social media's capabilities (Milan, 2015). Identity-work, the discursive process through which identities are made available to participants and observers, is a way of conceptualizing the ways Twitter users co-construct the American symbol of national parks. We focus on how historical images and discourse help shape identities on Twitter's networked sphere by questioning how political discourse strategies used by the national parks' rogue Twitter accounts are constructed, and how the content of their tweets reflects and shapes an American identity.

\section{Methods}

We rely on theoretical and methodological frameworks from an array of scholars. The approach we take to analyzing how people talk about national parks as a US symbol on Twitter is through CDA. We turn to Foucault (1972) to observe how discourse is based on social identities and how it functions rhetorically. Tracy and Robles' (2013) concept of identity-work is used to focus on how everyday talk constructs identities, as well as Foucault's (1972) notion of discursive formation as "the principle of dispersion and redistribution, not of formulations, not of sentences, not of propositions, but of statements" (p. 107), which are conceptualized in history. Such statements, or rules that make a statement meaningful, operate within defined systems and conceptual possibilities that are based on particular time periods in which they are occurring.

CDA has the potential to reveal the struggle against social and political inequality within exchanges, while also allowing for the identification of 
emergent discourse practices (Fairclough, 2013). In particular, we focused on conducting a positive critique, where the analysis focused on "how people seek to remedy or mitigate" social wrongs (Fairclough, 2013, p. 7). With this orientation, various discourses were brought together through the understanding of struggles, where alternative discourses emerged as strategies of resistance against dominant, historical discourses.

The above-mentioned authors direct how we analyze various Twitter accounts and the content within their tweets, as pertaining to threat, censorship, and identity building regarding America's national parks. In addition, we consider the ways in which culturally specific discursive moves are meaningful and reflect the cultural values of the discursive actors themselves. Further, our analysis focuses on the use of socially significant rhetorical statements that construct ideals of identity and struggle.

We analyzed three accounts that were verified by Snopes as operated by NPS employees (Binkowski, 2017) and that had the most followers: @ AltMountRainier, @BadHombreNPS, @AltYelloNatPark. Snopesapproved accounts were chosen because anyone can create a Twitter account and name it with a "national park" in its name. Snopes, one of the largest fact-checking sites (Graves, 2016), had identified accounts that were created and managed by national park government employees. All three accounts were created between January 24 and January 26, 2017. We collected tweets posted by these accounts from January 24th, 2017 until February 15th, 2017. These dates were selected because the rogue NPS Twitter accounts received most media coverage and public attention during this time, as they defied government and its policy. Tweets were identified by using Twitter's advanced search engines, in which we plotted the desired dates and account handles. The 469 tweets that were collected were all publicly available. In addition, the accounts and their tweets received a great deal of public attention in various news media outlets both in and outside the United States, effectively minimizing ethical concerns surrounding the identification of the authors.

As a research team, we analyzed the data set individually and later discussed our observations and findings collectively, guided by the following research question: How do alternative/rogue national park Twitter accounts draw on historic discourses of American nationalism to construct an American identity? Through our collective discussion, we made sense of the ways in which these accounts were addressing different political issues, engaging citizens and Twitter followers, and promoting their 
profile. We also identified what other strategies the accounts employed that relied on different American ways of being as well as constructing American national identity.

\section{FINDINGS}

All accounts under investigation relied heavily on discourses based on the historical conceptualization of national parks. In particular, discourses were related to the nationalistic and presidential ideals ingrained in the conception of the parks, including historic figures and pristine images of wilderness. Such discourses were based on meanings that have been historically used and are central to the public conception of what a national park may stand for, particularly related to wilderness (Nash, 2014). Drawing on these different tropes allowed the tweets to construct a new identity for the parks - as sites of discursive resistance and democracy, in which US national identity is built on the resistance of censorship. Such discourses used particular discursive formations based on newly generated meanings attributed to doing counteractive tweeting. We conceptualize counteractive tweeting as a communication practice that challenges the status quo and institutional censorship. The key to counteractive tweeting comes from self-framing, as well as the type of discourse in which the account/tweet is engaging with to exert mitigation or change.

We identified several discourse strategies used by the rogue accounts, which performed identity work. Such strategies were seen across the different accounts, with some tweets simultaneously drawing on multiple strategies. The three discourse strategies used in the effort to reclaim the National Parks' historic mission included: evoking nationalism, upholding democratic values, and resisting the government. These are described below.

\section{Evoking Nationalism}

Based on our review of the physical national parks and our analysis of the different rogue accounts, we identified ways in which these accounts evoke nationalism as a discursive strategy to establish a shared sense of identity. On February 9th, 2017, @AltYelloNatPark tweeted "The Upper Geyser Bassin [sic] is dominated by tough crystalline Silicate called Geyserite which allows pressure to build and geysers to form," alongside the tweet a photo of the geyser (Fig. 2.1), where the invocation of pristineness and wildness, through the lens of a photographic composition, highlights important notions of American landscapes as considered in the section on 


\section{AltYellowstoneNatPar @AltYelloNatPark · Feb 9}

The Upper Geyser Bassin is dominated by a tough crystalline Silicate called

Geyserite which allows pressure to build and geysers to form

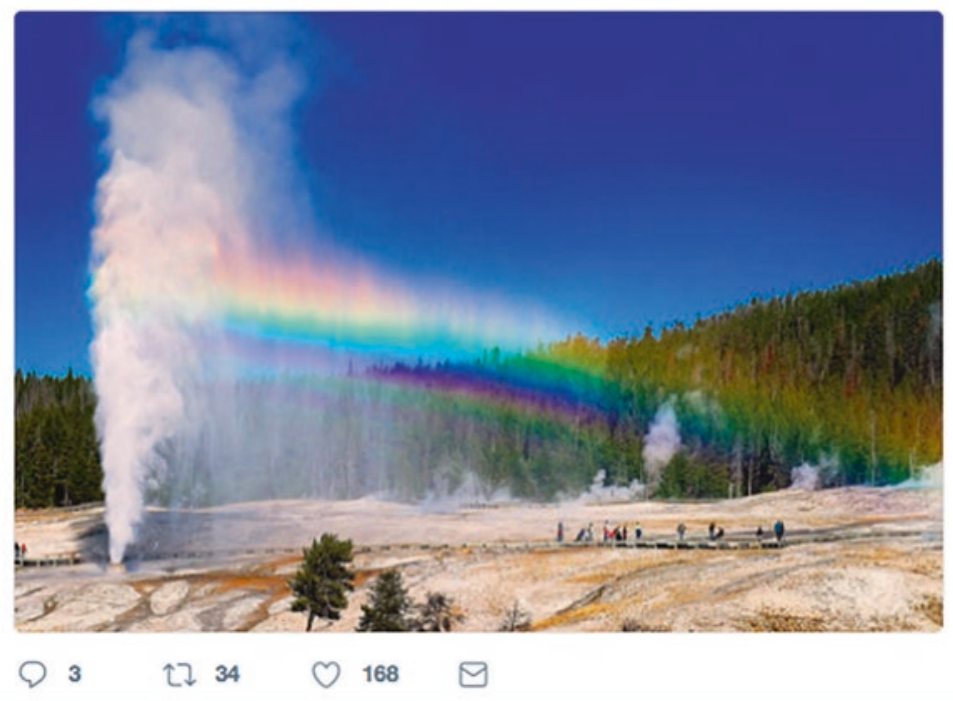

Fig. 2.1 Tweet shared by @AltYelloNatPark account on February 9th, 2017. "Yellowstone Geyser Rainbow," photo credit: Larry Gerbrandt. https://www. flickr.com/photos/larrygerbrandt/292124275. All rights reserved

national parks above. Similarly, @BadHombreNPS tweeted on January 31st, that "The Badlands erode at the rapid rate of about one inch per year, which is nothing compared to the current rate of erosion in our government." This was accompanied by a photograph of the park with the Black Hills in the background, highlighting the connection between land, government, and the American public. ${ }^{1}$

The @BadHombreNPS account released the following tweet on February 1st, 2017 (Fig. 2.2) "Protecting our \#wilderness should never be a partisan issue. It's our world and it deserves our protection. \#resist." This tweet was a comment added to a retweet by @WildernessSociety: “One issue that unites voters across the West: Let's protect \& preserve our

\footnotetext{
${ }^{1}$ See tweet here: https://tinyurl.com/badhombrebadlands
} 


\section{Protecting our \#wilderness should never be a partisan issue. It's our world, and it deserves our protection. \#resist}

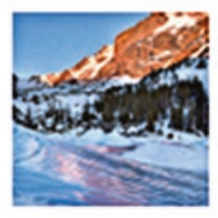

Wilderness Society $\bullet$ GWilderness

One issue that unites voters across the West: Let's protect \&

preserve our public lands on.rgj.com/2kSQQ8I via

ตBBenSpillman \#OurWild

12:39 PM - 1 Feb 2017

342 Retweets 659 Likes

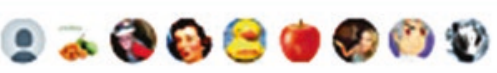

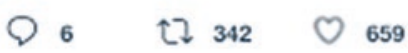

Fig. 2.2 Tweet shared by @BadHombreNPS account on February 1st, 2017. "Tilted ice, rosy sunrise," photo credit: Steven Bratman. https://www.flickr.com/ photos/darkdenver/6971654379. Some rights reserved

public lands on.rgj.com/2kSQQ81 via @ByBenSpillman \#OurWild.” The original tweet from @WildernessSociety included an image from Rocky Mountain National Park. A snowy pristine landscape with mountains and smooth sunlight was showcased, showing pine trees covered with snow that reflected the natural colors and remoteness of the landscape of the American park. The fact that this is a retweet is important to our analysis because of the connection and construction of a narrative in which the landscape represents both voting sides of the political spectrum. The link posted by @WildernessSociety redirects the user to an article called "UPDATED Poll: Trump and non-Trump voters agree on public lands," published by the Reno Gazette Journal. The American West's identity, accordingly, is not based on voter partisanship, but rather on what is shared across American identity: the preservation of the American scenery via the National Parks. 
This connection to preservation, we found, is maintained through the use of images and names of historical figures. On February 1st, 2017 @ BadHombreNPS tweeted "Another morning \#wilderness thought by John Muir. Wake up and smell the \#resistance." This was accompanied by an image of John Muir and Theodore Roosevelt with the quote "Thousands of tired, nerve-shaken, over-civilized people are beginning to find out going to the mountains is going home; that wilderness is a necessity... John Muir" (Fig. 2.3). The tweet refers to a nostalgic past in which presidents and environmentalists worked together, by evoking both Roosevelt and Muir within the same tweet. Similar sentiments are expressed in other tweets, such as this tweet posted on January 29th, by @AltYelloNatPark: "In solidarity with everyone who loves the parks. AltYellowNatPark is dedicated to the preservation of our wildlands." This is accompanied by an image of Theodore Roosevelt in front of the American flag with the

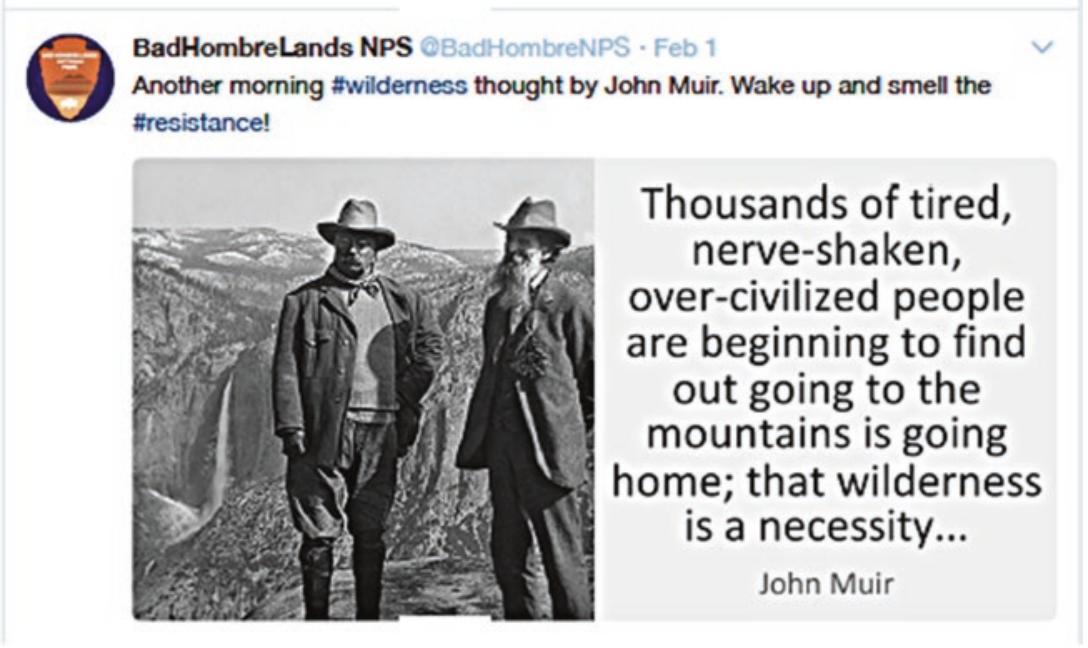

Fig. 2.3 Tweet shared by @BadHombreNPS account on February 1st, 2017. "Roosevelt and Muir at Glacier Point," National Park Services. https://www.nps. gov $/ \mathrm{media} /$ photo/gallery-item.htm?pg=0\&id=B15B62A7-155D-4519-3EF744 2 B 3F6E7AF 8 \& gid=B 17 BC4E 5-155D-4519-3EC6B73FCE2806A8. Public domain 
quote: "Patriotism means to stand by the country. It does not mean to stand by the president or any other public official - Theodore Roosevelt." 2

The images used in such tweets lead us back to constructions established at the time of the inception of the NPS (Runte, 2010), referencing ideals of preservation that are tied to nationalistic notions (Pezzullo \& Cox , 2018). This particular discursive strategy is observed throughout the tweets posted by the different rogue accounts. As part of such a strategy, different themes of nationalism were observed through references to wilderness, invocation of the past, and representations of American landscape and fauna. We discuss each of these themes below.

Wilderness The rogue national parks accounts rely on previous notions and perceptions of American identity through the use of images of landscapes specific to each national park, as observed in the tweet above from @AltYellowNatPark. In the past, images inspired comparisons between the American scenery and European art and architecture (Runte, 2010). Such images ran parallel to ideals of the American Wild West and the concept of wilderness as a unifying aspect of American identity (Nash, 2014). The continuous use of this historical strategy strengthens different claims made by the accounts that American landscapes and their preservation are a unifying factor.

The use of wilderness photography and the depiction of pristine nature allow tweets to rely on discourses that have continued to construct the United States through depictions in paintings and photography (i.e. Bierstadt 1863 The Rocky Mountain, and Ansel Adams' 1960 Moon over Half Dome). Moreover, the discourse of pristine lands and preservation through images is continuously used by many American environmentalists and personalities (DeLuca \& Demo, 2000).

This discourse strategy has been used in the past to establish an identity connected to place, specifically in relation to a landscape that is different from European scenery (Runte, 2010). It was also used to connect ideals of democracy instilled in the foundation of national parks (Tyrrell, 2012) and heritage unique to the US identity (Nash, 2014). From this point of view, the tweeted images perpetuate these notions and call attention to governmental actions that may disrupt or destroy such places of

\footnotetext{
${ }^{2}$ See tweet here: https://tinyurl.com/rooseveltonpatriotism
} 
attachment, where community sentiment and identity are bonded (Altman \& Low, 1992).

Invoking the Past The use of figures such as John Muir and Theodore Roosevelt, including the iconic photo taken at the top of Glacier Point in 1903 (Fig. 2.3), arguably elicit nostalgia to an American identity that does not appear to be recognized by the Trump administration. This nostalgia is based on the historical reputation of Roosevelt who continuously advocated wilderness preservation (Pezzullo \& Cox, 2018) and is placed in contrast to the Trump administration's actions that are presented as negative to the environment, as highlighted in this tweet, also mentioned above: "The Badlands erode at the rapid rate of about one inch per year, which is nothing compared to the current rate of erosion in our government" @BadHombreNPS. In contrast, the January 25th tweet by @ AltYelloNatPark discussed above makes a reference to Roosevelt's quote: "Patriotism means to stand by the country. It does not mean to stand by the president or any other public official." This strategically places government in a position - at the forefront of the flag-of protector of the environment as a form of patriotic value. Other figures, such as John Muir, appear in this image in order to convey 'wilderness thoughts' about the American landscape.

By continuously referencing presidential figures that were influential within the preservation movement, and especially those who were involved in the creation of national parks, a link is made to the idea that nationalism, and not environmentalism per se, was behind the creation of the national parks (Tyrrell, 2012). The use of wilderness discourses draws attention to the kinds of identities that place national parks as the "highest incarnation of American attitudes on nature" (Tyrrell, 2012, p. 1), representing the goodness within people and wilderness (Thoreau, 1990).

Theodore Roosevelt is often cited and featured in tweets by the actual national parks' accounts, as well as in tweets by the rogue national parks' profiles. This practice centers on the concept of public access to lands as "America's best idea" (Burns, 2009), and is something that has been done across different media productions, including books (e.g. The Wilderness Warrior, Douglas Brinkley) and documentaries (e.g. Theodore Roosevelt: The Early Years, Ken Burns; John Muir in the New World, Catherine Tatge). This keeps historical figures present in the public's consciousness. Evoking past presidents also highlights the nineteenth-century 
nationalistic endeavor (Nash, 2014) that was part of this idea and included the American belief in saving beautiful landscapes. Consequently, this sees the land as "inspirational" (Runte, 2010). US identity, in this sense, is continuously tied to romantic narratives ingrained in the public consciousness about Native Americans, the pioneers, and the Wild West. These have influenced the relationships between humans and nature, as well as between people and the nation both in the past as well as today (Schwartz, 2006).

This discourse of a nostalgic past continues to serve nationalistic exigencies that aim to orient the perception of the landscape as an American cultural icon and imbue the American narrative with discourses of wilderness (DeLuca \& Demo, 2001). The tweets by the rogue accounts that reference a sense of pristine landscapes relay the nostalgic sense of an untouched and preserved place. Ultimately, the national parks' importance as signifiers of nationalistic identity, as constructed symbol, provides a desirable clarity of meaning for the dissemination of nationalistic rhetoric (Rennie, 2006).

American Landscapes and Fauna Landscapes were but one aspect of nature that was explored by the rogue accounts when evoking nationalism. The accounts also heavily used the depiction of local fauna. Moreover, within the use of this strategy, the accounts engaged in satire and personification of the nonhuman.

Animal posts by the rogue accounts referenced nationalist notions associated with the bald eagle and other species typically used as symbols of National Parks. @BadHombreNPS posted the following on February 7th: "The Western Meadowlark is the state bird of 6 states-although its yellow belly and illiteracy makes it a great presidential mascot as well" (Fig. 2.4); and on January 26th: "Prairie dogs' tiny hands are great for digging themselves into holes. That's a good thing for prairie dogs. Not so great for a president." ${ }^{3}$ These tweets tag on to the current popularity of animal memes, including what has been known as 'advice animals' (Vickery, 2014; Shifman, 2013). The particular 'advice animals' meme genre tends to use macro images, and "build[s] on a set of stock characters that represent stereotypical behaviors" (Shifman, 2013, p. 112).

\footnotetext{
${ }^{3}$ See tweet here: https://tinyurl.com/badhombreprairiedog
} 


\section{BadHombreLands NPS @BadHombreNPS - Feb 7}

Replying to @BadHombreNPS

The Western Meadowlark is the state bird of 6 states- although its yellow belly and illiteracy makes it a great presidential mascot as well.

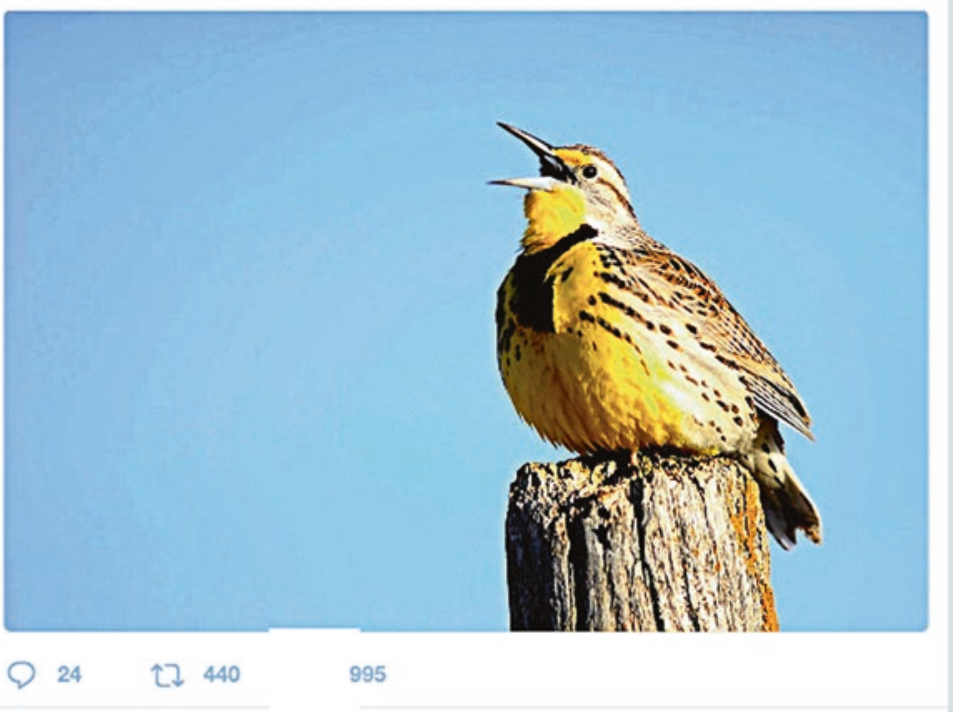

Fig. 2.4 Tweet shared by @BadHombreNPS account on February 7th, 2017. "Western Meadowlark," photo credit: Rick Bohn. Author: USFWS MountainPrairie. https://www.flickr.com/photos/usfwsmtnprairie/25404358384/. Some rights reserved

The tweet posted on January 27th by @BadHombreNPS was used to evoke nationalistic ideals alongside political satire: "The Bald Eagle, along with the rest of the free world, is now at risk of being wiped out by the noxious irritant known as DJT" (Fig. 2.5).

The bald eagle, part of the seal of the United States, is used as a symbol that embodies particular American values associated with the democratic "free world." The bald eagle was adopted as a national totem in 1782, and it has played a prominent role in American iconography and folk art, being a "flaglike declaration of statefulness" (Zelinsky, 1984, p. 286). Using DJT (Donald J. Trump) as a play on DDT constructs the president as 


\section{BadHombreLands NPS BadHombreNPS · Jan 27}

Replying to @BadHombreNPS

The Bald Eagle, along with the rest of the free world, is now at risk of being wiped out by a noxious irritant known as DJT.

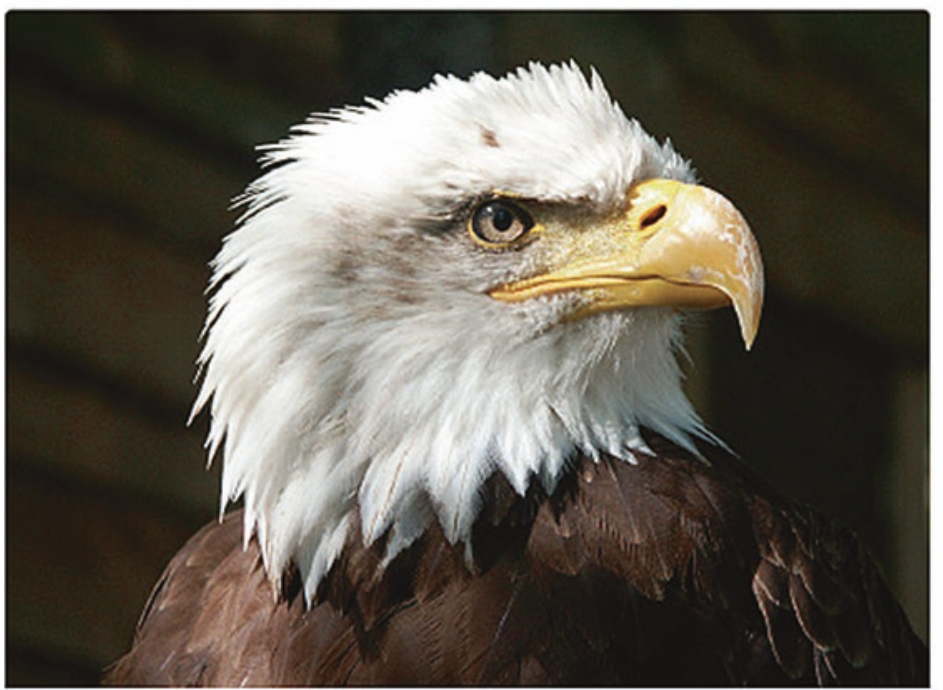

Fig. 2.5 Tweet shared by @BadHombreNPS account on January 27th, 2017. "Raptor," photo credit: Jean Beaufort. https://www.publicdomainpictures.net/ es $/$ view-image. php?image $=232818$ \&picture $=$ raptor. Some rights reserved

antienvironment by portraying notions of an environmental struggle against toxic chemicals (Carson, 2002).

The use of satire through locally significant fauna and landscapes is seen in different tweets. @AltMountRainier posted in January 27th: "Hey, \#Trump! When you mount me, make sure you use the easiest \#ice/\#rock climb, Disappointment Cleaver, It's the easiest way to the top (mountainemoji)" (Fig. 2.6), showcasing the use of landscapes. Essentially, tweets' use of charismatic animals and beloved landscapes, such as the "Disappointment Cleaver," draws on political satire to challenge the president's position on the environment, which includes his denial of climate change and environmental policy (Kristof, 2017; Light \& Hale, 2018). 
七】 AltMountRainier $\in$ Retweeted

AltMountRainier @ @AltMtRainier · Jan 27

Hey, \#Trump!

When you mount me, make sure you use the easiest \#ice/\#rock climb, Disappointment Cleaver. It's the easiest way to the top.

Q 4 七` $49 \quad$ ○ 145

Fig. 2.6 Tweet shared by @AltMtRainier account on January 27th, 2017

\section{Upholding Democratic Values}

As previously discussed in this chapter, the US NPS represents more than just land dedicated to the restoration of wildness. The US national identity and the preservation of a democratic society is constructed within the ideals associated with the National Park Service. In the following tweets, the identification of "we" and calls for "everyone" to play a part in resisting the administration's policies represent the collective unity that is claimed to be embedded within the networked public sphere of those in opposition to what is perceived as the mainstream, hegemonic discourse, and particularly the antienvironment rhetoric produced by the Trump administration.

Following the censorship of the Badlands National Park Twitter account, the fear of being silenced became a very real possibility for those working for the NPS. Several tweets address this concern, such as "We are Yellowstone, and we will not be silenced," posted by @AltYelloNatPark on January 25th, and "Everyone has a part (or parts) to play! Inaction and silence are not options anymore. \#resist" shared by @BadHombreNPS on January 29th. A tweet by @altNOAA focused specifically on the silencing of media outlets: "The Senior Counselor to the President of the United States just said the media should 'keep its mouth shut'. \#resist."

This often-repeated call was seen through the use of retweets as well, as the rogue accounts called people into action and supported each other's accounts in this endeavor. The @AltYelloNatPark account, for instance, tweeted "This is critical people, please retweet. We will not be silenced," a reference to a tweet from @altNOAA that stated: "You can't just sweep \#ClimateChange under the rug and hope it gets away. It won't. Demand the WH website be restored. \#science \#masa." More so than references to a collective identity, the repeated mantra of "we will not be silenced" in 
the above tweets and countless others from these rogue National Park accounts highlight the fear of censorship and, more broadly, NPS erasure. The "we" calls upon those who embody the American identity of sharing and having an equal say, which is something that is central to a democracy and a functioning public sphere.

Silence can hold significant meanings that are subject to cultural variations and norms, participants' interactions, and overarching community expectations (Muñoz, 2014). Within dominant American discourses, silence is often seen as negative, undesired, or harmful, connotes the negation of a person's being, and signals that social institutions have been broken or corrupted (Carbaugh, 2005). By repeatedly stating "we will not be silenced," the accounts drew on this "discourse of silence" to indicate that Trump's silencing of NPS employees demonstrates the corrupt and broken nature of US political institutions. Furthermore, to silence NPS employees (who represent the parks) constituted a threat to their identity, and therefore a threat to the notion of a US identity that relies on ideals of a shared nation with pristine wilderness and environmental beauty (Nash, 2014). Hence, the accounts emphasized that everyone had a part to play in raising their voice to counteract the perceived negation of national identity perpetrated by the Trump administration.

\section{Resisting the Government}

Discourses of resistance were prevalent throughout the tweets analyzed for this study. They included calls to action, such as: "We must all act in whatever measure we can, no act of resistance is too small. Write, Speak, do something. Everything helps," posted by @AltYelloNatPark on January 26th; and @BadHombreNPS's tweet: "Signing off for the evening. Thanks to all of you for keeping the \#resistance momentum alive in the name of \#science and \#wilderness."

Throughout their tweeting, the rogue accounts drew on a number of resistance strategies. These included retweets, engagement with other accounts and the public, as well as reaching beyond the platform when calling upon the public to contact their representatives via Faxtivism. ${ }^{4}$ Many metaphorical codes that represent activism and militarism are

\footnotetext{
${ }^{4}$ When elected representatives would not answer phones, the accounts encouraged people to send faxes. They implemented the hashtag \#faxtivism to encourage participants to act outside of the online platform.
} 
employed in the language used, such as "fighting" and "warrior." The rogue accounts also used activism discourse, such as "making your voices heard," "making yourselves heard is still important," "show up and make your voice heard." These connect to notions central to US identity regarding the free world, freedom of speech, democracy, and anticensorship. The idea of collective identity, constructed from the shared goal of resisting government, is necessary for the online mobilization observed around the rogue accounts (Tindall \& Robinson, 2017).

There were overlaps among the different strategies employed in tweets, combining resistance with other strategies mentioned earlier here. Consider, for example, a tweet by @BadHombreNPS that includes a screenshot of the following: "In every walk with nature one receives far more than he seeks. John Muir" accompanied by "Good morning, \#WildernessWarrior! This simple quote by John Muir reminds us To why we \#resist for \#Nature." Tweets of resistance also promote acquisition of information and learning about how to engage in action: "A Practical Guide to Resisting the Trump Agenda \#WeWillWin" posted by @ AltMountRainier on February 10th with the link indivisible.org.

For the rogue national park Twitter accounts, resisting online evoked the sense of nationalistic duty and the preservation of one's own identity. Talk, as resistance, situates the rogue accounts within the power struggles observed between agencies and government officials. The discourse of resistance highlights the corruption of democratic values and functions as an operationalized discourse strategy, which Fairclough (2013) suggests is implemented in order to contribute to social transformation.

\section{Discussion}

The early paintings and photographs of the different national parks were the vehicle through which the United States associated its natural landscapes with its national identity. This discourse was constructed in order for the United States to differentiate itself from Europe, and later these signs came to embody preservation, wilderness, and public access as a representation of high standards of democracy and national identity. The godly presence of majestic mountains and landscapes (Thoreau, 1990), as well as American fauna, were used by the alternative accounts to challenge and criticize the government in a civil manner. The use of fauna, arguably, was a way to soften criticism of the administration, making the critiques easier to disseminate and for different political identities to engage with. 
Because of their position as a US symbol, the rogue national parks accounts appeared to perform a watchdog role, striving for the government to uphold democratic values and verifiable scientific facts.

The rogue accounts extended their discourses from what can be considered micro discursive strategies (of calling out for breaking silence and using \#resist) to macro US identity symbols, such as landscape images and calls for democratic values. Identity-work has aided in demonstrating how the accounts build through discourse the desired identity to be displayed and hailed to the public via the use of counteractive tweeting. By constructing the identity of being a national symbol, the accounts simultaneously helped craft the alternative discourse happening through Twitter in the context of historical conception and meaning (Foucault, 1972). Through CDA, we noted how rogue accounts resisted government pressure and tested the boundaries of censorship on Twitter.

The rogue accounts functioned as sites of discursive resistance to the Trump administration's communication agenda. This was accomplished by continuously drawing on discourses of US national prestige to construct identities of resistance and situate themselves within larger historical discourses of national parks. The dominant governmental discourse against climate change, via the government's censorship, influenced the formation of an emergent discourse practice within Twitter. In particular, the discourse strategies used are a demonstration of discontinuity, as the observed accounts constructed a new identity for the parks-as sites of discursive resistance and a force for democratic values. As such, they articulated a US national identity built upon the fight against censorship and for freedom of expression.

We should be aware that in the creation of meaning about the identity of national parks, certain ideas were foregrounded and others were backgrounded or deleted. The values connected to the National Parks by the rogue accounts follow the mythical American narrative "that covers up a much more complicated and troubling history" (DeLuca, 2010, p. 490). Our research indicated that during the timeframe of our analysis, there were no mentions of Native American struggles or discourses, specifically, the killing and displacement of indigenous populations who inhabited the areas claimed as public (Runte, 2010), that counter the historically situated, nationalistic value of public lands. The democratic ideals employed and highlighted by the rogue accounts, therefore, hinder a fuller and historically more accurate understanding of the process of national park 
creation, which was often antidemocratic and embedded in deeply troubling race and class struggles (DeLuca, 2010; Finney, 2014).

\section{Conclusion}

The rogue NPS accounts strove to fight repression of the discussion surrounding climate change and, in doing so, may have motivated other Twitter users to contact elected officials about these issues. The accounts did so by drawing on a historical discourse of nationalist identity, which we have discussed in this study. That nationalist identity resulted in the accounts subtly reinforcing the ideologies of the supremacy of a benevolent US nation-state that cares for nature and the environment, while avoiding any discussion of aspects of the parks' formation that invariably resulted in the displacement of native people (DeLuca, 2010). The positive framing and focus on particular historical symbols and historical discourses were used in order to mobilize groups against Trump, and against his censorship regarding climate change.

Ultimately, wilderness continues to be one of the basic ingredients (Nash, 2014) shaping American identity and it is used within Twitter to maintain notions of collective group identity through its networked public sphere. The overall construction of preservation of wilderness as a form of resistance will continue to be a useful strategy as we move toward a future where the value of wilderness and natural preservation will continue to be argued about, and censorship and misinformation about climate change will continue to be challenged.

Acknowledgments The authors would like to thank all of the National Park Service workers who dedicate their time in the pursuit of justice and the preservation of nature. The authors would also like to thank Drs. Phaedra Pezzullo, Karen Tracy, and Timothy Kuhn for their input during the development of this research project, and the book editors who provided valuable feedback.

\section{REFERENCES}

Altman, I., \& Low, S. M. (1992). Place attachment. New York: Plenum Press. Ausserhofer, J., \& Maireder, A. (2013). National politics on twitter: Structures and topics of a networked public sphere. Information, Communication \& Society, 16(3), 291-314. 
Binkowski, B. (2017, June 1). Twitter's alts and rogues. Snopes. Retrieved from: https://www.snopes.com/news/2017/06/01/alts-and-rogues /

Brinkley, D. (2009). The wilderness warrior. New York: Harper Collins Publishers. Burns, K. (Director). (2009). The National Parks: America's best idea [Motion picture]. Arlington, TX: PBS.

Carbaugh, D.A. (2005). Cultures in conversation. Mahwah, NJ: Lawrence Erlbaum.

Carson, R. (2002). Silent spring (40th Anniversary ed., 1st Mariner Books ed.). Boston: Houghton Mifflin.

Chen, W., Tu, F., \& Zheng, P. (2017). A transnational networked public sphere of air pollution: Analysis of a twitter network of PM2.5 from the risk society perspective. Information, Communication \& Society, 20(7), 1005-1023.

Davis, W. (2017, January 25). Rogue National Park accounts emerge on Twitter amid social media gag orders. National Public Radio. Retrieved from http:// www.npr.org/sections/alltechconsidered/2017/01/25/511664825/ rogue-national-park-accounts-emerge-on-twitter-amid-social-mediagag-orders

DeLuca, K., \& Demo, A. (2001). Imagining nature and erasing class and race: Carleton Watkins, John Muir, and the construction of wilderness. Environmental History, 6(4), 541-560.

DeLuca, K. M. (2010). Salvaging wilderness from the tomb of history: A response to The national parks: America's best idea. Environmental Communication, 4(4), 484-493.

DeLuca, K. M., \& Demo, A. T. (2000). Imaging nature: Watkins, Yosemite, and the birth of environmentalism. Critical Studies in Media Communication, $17(3), 241-260$.

Diaz, D. (2017, January 24). Badlands National Park deletes tweets on climate change. CNN. Retrieved from https://www.cnn.com

Fairclough, N. (1989). Language and power. London: Longman.

Fairclough, N. (2013). Critical discourse analysis: The critical study of language. Hoboken, NJ: Taylor \& Francis.

Finney, C. (2014). Black faces, white spaces: Reimagining the relationship of African Americans to the great outdoors. Chapel Hill, NC: The University of North Carolina Press.

Foucault, M. (1972). The archaeology of knowledge (1st American ed.). New York: Pantheon.

Frome, M. (2015). Rediscovering National Parks in the spirit of John Muir. Salt Lake City, NV: University of Utah Press.

Graves, L. (2016). Deciding what's true: The rise of political fact-checking in American journalism. New York: Columbia University Press.

Hahn, A., Judd, C. M., \& Park, B. (2010). Thinking about group differences: Ideologies and national identities. Psychological Inquiry, 21(2), 120-126. 
Herb, G. H., \& Kaplan, D. H. (Eds.). (1999). Nested identities: Nationalism, territory, and scale. Rowman \& Littlefield Publishers.

Howkins, A., Orsi, J., \& Fiege, M. (Eds.). (2016). National parks beyond the nation: Global perspectives on "America's best idea”. Norman, OK: University of Oklahoma Press.

Kristof, N. (2017, January 6). As Donald Trump denies climate change, these kids die of it. New York Times. Retrieved from https://search-proquest-com.colorado.idm.oclc.org/docview/1856361381 ?accountid=14503

Light, A., \& Hale, B. (2018). Year one of Donald Trump's presidency on climate and the environment. Ethics, Policy \& Environment, 21(1), 1-3.

Milan, S. (2015). From social movements to cloud protesting: The evolution of collective identity. Information, Communication \& Society, 18(8), 887-900.

Milan, S. (2016). Liberated technology: Inside emancipatory communication activism. In E. Gordon \& P. Mihailidis (Eds.), Civic media: Technology, design, practice (pp. 107-124). Cambridge, MA: MIT Press.

Milan, S. (2017). Data activism as the new frontier of media activism. In V. W. Pickard \& G. Yang (Eds.), Media activism in the digital age (pp. 151-163). London: Routledge.

Muñoz, K. L. (2014). Transcribing silence: Culture, relationships, and communication. Walnut Creek, CA: Left Coast Press.

Nash, R. (2014). Wilderness and the American mind (5th ed.). New Haven, CT: Yale University Press.

Noe, R. (2017, January 26). Here's a list of all the U.S. govt's rogue Twitter accounts fighting Trump's crackdown on science. Core 77. Retrieved from http://www.core77.com/posts/60230/Heres-a-List-of-All-the-US-GovtsRogue-Twitter-Accounts-Fighting-Trumps-Crackdown-on-Science

Obar, J. A. (2014). Canadian advocacy 2.0: An analysis of social media adoption and perceived affordances by advocacy groups looking to advance activism in Canada. Canadian Journal of Communication, 39(2), 211-233.

Perez, S. (2017, January 27). Rogue National Park Service Twitter account says it's no longer run by government employees...but may be it never was. TechCrunch. Retrieved from https://techcrunch.com/2017/01/27/ rogue-national-park-service-twitter-account-says-its-o-longer-run-by-government-employees-but-maybe-it-never-was /

Pezzullo, P. C., \& Cox, J. R. (2018). Environmental communication and the public sphere (5th ed.). Los Angeles: Sage.

Rennie, A. (2006). The importance of national parks to nation-building: Support for the National Parks act (2000) in the Scottish parliament. Scottish Geographical Journal, 122(3), 223-232.

Ross-Bryant, L. (2005). Sacred sites: Nature and nation in the U.S. National Parks. Religion and American Culture: A Journal of Interpretation, 15(1), 31-62. 
Runte, A. (2010). National Parks: The American experience (4th ed.). Lanham, MD: Taylor Trade.

Scherman, A., Arriagada, A., \& Valenzuela, S. (2015). Student and environmental protests in Chile: The role of social media. Politics, 35(2), 151-171.

Schwartz, S. (2006). A theory of cultural value orientations: Explication and applications. Comparative Sociology, 5(2), 137-182.

Shifman, L. (2013). Memes in digital culture. Cambridge, MA: MIT Press.

Shirky, C. (2008). Here comes everybody: The power of organizing without organizations. New York: Penguin.

Spillman, B. (2017, January 31). Updated poll: Trump and non-Trump voters agree on public lands. Reno Gazette Journal. Retrieved from https://www.rgj.com/story/life/outdoors/recreation/2017/01/31/ poll-trump-and-non-trump-voters-agree-public-lands/97307654/

Stoddart, M. J., \& MacDonald, L. (2011). "Keep it wild, keep it local": Comparing news media and the internet as sites for environmental movement activism for jumbo pass, British Columbia. Canadian Journal of Sociology, 36(4), 313-336.

Thoreau, H. D. (1990). Walden. Philadelphia: Courage Books.

Tindall, D. B., \& Robinson, J. L. (2017). Collective action to save the ancient temperate rainforest: Social networks and environmental activism in Clayoquot sound. Ecology and Society, 22(1), 481-494.

Tracy, K., \& Robles, J. S. (2013). Everyday talk: Building and reflecting identities (2nd ed.). New York: The Guilford Press.

Tudoroiu, T. (2014). Social media and revolutionary waves: The case of the Arab spring. New Political Science, 36(3), 346-365.

Tyrrell, I. (2012). America's national parks: The transnational creation of national space in the progressive era. Journal of American Studies, 46(01), 1-21.

Vickery, J. R. (2014). The curious case of confession bear: The reappropriation of online macro-image memes. Information, Communication \& Society, $17(3), 301-325$.

Wes, S. (2017, February 7). Why hikers need hunters and vice versa. Outside. Retrieved from https://www.outsideonline.com/2155826/public-landsdefense-glimmer-bi-partisan-cooperation

Zelinsky, W. (1984). O say, can you see?: Nationalistic emblems in the landscape. Winterthur Portfolio, 19(4), 277-286. 